\title{
INFLATION AND CAPITAL STRUCTURE
}

José Noguera

\section{CERGE-EI, Charles University}

\section{P.O. Box 882, Politických vězňů 7, 11121 Prague 1}

Phone: 420-2-240.05.107

\begin{abstract}
$\underline{\text { Abstract }}$
This essay is a contribution to the empirical literature on the effect of inflation tax on capital structure. A simple empirical model considering the main results of the current theoretical development is studied, using microdata from a number of American corporations.
\end{abstract}

\begin{abstract}
Abstrakt
Tento článek je příspěvkem k empirické literatuře studující dopad inflace na strukturu kapitálu. Jednoduchý empirický model používající mikroekonomická data o amerických korporacích je analyzován s ohledem na hlavní poznatky současné teorie.
\end{abstract}




\section{INFLATION AND CAPITAL STRUCTURE}

\section{CERGE-EI \\ José Noguera, CERGE-EI, Charles University, Prague}

\section{INTRODUCTION}

Modigliani-Miller's (1958) classic paper gave origins to a huge literature concerning the behavior of firms' capital structure, and the optimal dividend policy under a variety of scenarios. This essay concerns the effect of (steady) inflation on corporate financial leverage. Several possible links have been provided between both variables. In all cases the link is provided through the demand or supply of corporate bonds. For instance, Corcoran (1977), Zwick (1977), and DeAngelo and Masulis (1980) theoretically explain that inflation leads to more debt: since inflation lowers the real cost of debt, the demand for corporate bonds increases during inflationary periods. On the other hand, if corporate bonds' return becomes higher relative to stocks' return as inflation decreases, the aggregate demand of corporate bonds increases.

Another way to link these two variables is to consider tax structure. A seminal paper on the tax and capital structure literature is Miller (1977). He extends the Modigliani-Miller proposition for an economy with taxes, and argues that even in a world in which interest payments are fully deductible in computing corporate income taxes, the value of the firm, in equilibrium, will still be independent of its capital structure. Dammon (1988) states that Miller only determined the optimal level of debt for the aggregate corporate sector, and introduces uncertainty and progressive marginal tax rates. Further, Miller allows investors to freely choose their portfolio in his model and he 
concludes that marginal tax rates differ across states of nature depending on the taxable personal income, which does not necessarily equal the corporate tax rate. This prevents firms from adjusting their capital structure on a state-by-state basis and from maximizing the firm value.

If tax rates are quoted as percentages of nominal income, progressive taxes make inflation a source of government revenue since it may bring taxpayers to higher tax brackets. Since firms cannot adjust their optimal capital structure on a state-by-state basis, as in Dammon (1988), inflation affects capital structure and firm value. Thus, higher inflation fosters investors to sell bonds in exchange for stocks and hence firms' capital structure, measured as the debt-capital ratio, tends to drop.

Related to this literature, Dokko (1989) finds empirical support for a change in expected inflation to create a wealth redistribution between creditors (bondholders) and debtors (shareholders); Kelly and Miles (1989) incorporate the capital structure theory to model the response of nominal interest rates to expected inflation in a world with taxes; Platt et al. (1995) states that while distressed firms may prefer a no growth strategy, external pressures such as inflation may cause their sales to rise exogenously and develops a new sustainable growth rate formula that describes how much growth the firm with no new debt capacity can endure; Franks and Schwartz (1991) analyze whether innovations in good price volatility can explain changes in equity price volatility; and Hodder and Senbet (1990) develop a theory of capital structure in an international setting with corporate and personal taxes to characterize an international equilibrium with differential international taxation and inflation in otherwise perfect international capital markets. 
As the reader can easily realize, there are a number of possible indirect ways in which inflation may affect firms' capital structure. The empirical testing of these effects has been done mainly using aggregate measurements of the different variables involved in the models. This essay is a contribution to the empirical literature on the effect of inflation tax on the capital structure in which microdata of a number of American corporations is considered. The paper is structured as follows. Section II reviews the literature, identifies the different ways in which both variables are related, and shows a general model to analyze this relationship. Section III exposes the empirical tests and shows the results for forty major American companies. Section IV concludes.

\section{METHODOLOGY}

Theoretical models explaining the effects of inflation on capital structure establish links by examining how inflation affects the yield on equality and bond holding, and hence the demand and supply of corporate bonds. Kim and Wu (1988) nicely summarize them, and identify three major effects that they denominate: the Miller Effect, the Schall Effect and the DeAngelo-Masulis Effect. Here we add the Dammon effect.

Miller (1977) finds a positive relationship between the corporate debt level and the yield spread between corporate and municipal bonds. Given an income tax structure, an increase in the yield spread between corporate and municipal bonds implies a higher marginal investor's income tax rate. This fosters additional investors to acquire corporate bonds, and increases the debt ratio.

Schall (1984) argues that if the net yield on equities decreases, there will be a substitution effect of corporate bonds for equities since the yield on bonds becomes 
relatively higher. In fact, in this case investors are encouraged to change their portfolio to sell equities and to purchase bonds.

DeAngelo and Masulis (1980) prove that if the size of a firm's depreciation deduction increases, due to lessened tax shelter opportunities available for debt financing, the firm's debt ratio decreases.

The Dammon effect, stated in the introduction, means that a higher inflation rate makes investors sell bonds and purchase stocks, so the debt ratio tends to drop.

Let $B_{t}$ be the equilibrium level of corporate bonds, $S_{m t}$ the before-tax yield spread between corporate and municipal bonds, $S_{e t}$ the before-tax yield spread between corporate bonds and equities, $D_{t}$ the ratio of depreciation to total assets, and $T_{t}$ the inflation tax at some period $t$. Then, if the tax rates are constant, the Miller, Schall, DeAngelo-Masulis and Dammon Effects can be summarized in the following equation:

$$
B_{t}=\beta_{0}+\beta_{1} S_{m t}+\beta_{2} S_{e t}-\beta_{3} D_{t}-\beta_{4} T_{t}+e_{t},
$$

where $\beta_{1}, \beta_{2}, \beta_{3}$, and $\beta_{4}$ are all positive. Considering the Irving Fisher assumption that the expected nominal interest rate is the sum of the expected real rate and the expected rate of inflation, it follows that the nominal interest rate increases with inflation. Since nominal returns on common stocks tend to decrease with a higher inflation rate, an increase in the inflation rate makes the yield difference between corporate debt and equity increase. Considering the possibility of a lag in the investors' decisions, this effect is captured in the following equation:

$$
S_{e t}-S_{e t-1}=b_{1} \Delta P_{t}+b_{2} \Delta P_{t-1}+u_{e t} \quad b_{1}, b_{2}>0 .
$$

Hochman and Palmon (1985) show that the marginal investor's income tax rate increases with inflation in the presence of leverage-related costs, but the yield difference between 
taxable and nontaxable debt depends positively on the marginal investor's income tax rate. This can be formally expressed as

$$
S_{m t}-S_{m t-1}=c_{1} \Delta P_{t}+c_{2} \Delta P_{t-1}+u_{m t}, \quad c_{1}, c_{2}>0 .
$$

Also, it is a well known result that inflationary periods provoke a rising depreciation rate. This effect can be formally written as

$$
D_{t}-D_{t-1}=d_{1} \Delta P_{t}+d_{2} \Delta P_{t-1}+u_{d t}, \quad d_{1}, d_{2}>0 .
$$

Assuming that the inflation tax is positively related with the inflation rate, and considering (2), (3) and (4) in equation (1) we have

$$
B_{t}=\beta_{0}+\beta_{1} S_{m t-1}+\beta_{2} S_{e t-1}+\beta_{3} D_{t-1}+\gamma_{1} \Delta P_{t}+\gamma_{2} \Delta P_{t-1}+e_{t}
$$

which can be rewritten as

$$
B_{t}=B_{t-1}+\gamma_{1} \Delta P_{t}+\gamma_{2} \Delta P_{t-1}+e_{t}
$$

To consider a more general case, we slightly modify equation (5) to include a constant term, so empirical tests are made on the following equation:

$$
B_{t}=\gamma_{0}+\gamma_{1} B_{t-1}+\gamma_{2} \Delta P_{t}+\gamma_{3} \Delta P_{t-1}+e_{t}
$$

The coefficients $\gamma_{2}$ and $\gamma_{3}$ represent the combined effect of changes in the before-tax yield spread between corporate and municipal bonds, the before-tax yield spread between corporate bonds and equities, and the ratio of depreciation to total assets on the debt ratio through inflation. The sign of $\gamma_{2}$ and $\gamma_{3}$ depend on the relative strength of $S_{m t}, S_{e t}, D_{t}$, and $T_{t}$ on the firm's debt ratio. If $\gamma_{2}\left(\gamma_{3}\right)$ is positive, the effects of $S_{m t}$ and $S_{e t}$ dominate. If $\gamma_{2}\left(\gamma_{3}\right)$ is negative, the depreciation and inflation tax effect prevail, and if $\gamma_{2}\left(\gamma_{3}\right)$ is zero, both effects balance. 


\section{III.EMPIRICAL TESTS}

To test the main result in the last section, I combine time series for the period 1978-1996 and cross-sectional data from forty major American companies to test the relationship between the capital structure and the inflation rate. Data is provided by the Compu-Stat Database, and I use the Time Series Package (TSP) to compute regressions. The forty American corporations are Allegheny Teledyne, American Express, Amoco Corp., AT\&T, Avon Products, Bank of America, Bell Atlantic, Bethlemhem Steel Corp., Black and Decker, Boeing, Chrysler, Citicorp, Coastal Corp., Coca-Cola, Colgate Palmolive, Delta Airlines, Digital Equipments, Du Pont de Nemours, Eastman Kodak, Exxon, Federal Express, Ford Motors, General Electric, General Dynamics, General Motors, Heinz, Hewlett Packard, Intel, Johnson \& Johnson, McDonalds, Merck, Merrill Lynch, Microsoft, Mobil, Pepsi Cola, Sears Roebuck, Texas Instruments, Wal-Mart, Walt Disney Co., and Xerox Corp.

To find the appropriate estimator, we use the Breusch-Godfrey test to check autocorrelation for every firm's time series. Results are shown in Table 1 (in attachment). The null hypothesis of no autocorrelation is rejected in all cases at a significance level of 1 percent. Then, we compute the pooled least squared regression and obtain the following results:

\begin{tabular}{|c|c|c|c|c|c|c|}
\hline $\begin{aligned} B_{t}= & 4.20 \\
& (7.997) \\
& (0.525)\end{aligned}$ & $+\quad \begin{array}{c}B_{t-1} \\
(0.013) \\
(79.47)\end{array}$ & + & & ${ }_{t}^{P_{t}}$ & $\begin{array}{l}0.50 \Delta P_{t-1} \\
(3.155) \\
(-0.157)\end{array}$ & $+e_{t}$ \\
\hline$R^{2}=0.90$ & \multicolumn{4}{|c|}{ Pooled Residual Variance $=7,673.92$} & \multicolumn{2}{|l|}{$\mathrm{DW}=2.14$} \\
\hline \multicolumn{4}{|c|}{ Sum of Squared Residuals $=5,310,350$} & \multicolumn{2}{|c|}{ Sample Size $=696$} & F-Stat $=2133.6$ \\
\hline
\end{tabular}


The parentheses in the first row show standard errors of coefficients and the second row the t-stats. From this first regression, the capital structure seems to be completely explained by its past values.

The next step is to test heteroskedasticity. For that purpose, we apply the Lagrange multiplier test, White's general test and the Wald statistic to test the null hypothesis of equal variances, see Greene (1990, pp. 465-469). Based on the last squared results above and for every individual firm, the Lagrange multiplier statistic is $\mathrm{LM}=$ $75,823.26$, which is highly significant.

To use White's test, we regress the OLS residual in the last regression on a constant, $B_{t-1}, \Delta P_{t}, \Delta P_{t-1}, B_{t-1}{ }^{2}, \Delta P_{t}^{2}, \Delta P_{t-1}{ }^{2}, B_{t-1}{ }^{*} \Delta P_{t}, B_{t-1}{ }^{*} \Delta P_{t-1}$ and $\Delta P_{t}^{*} \Delta P_{t-1}$, so there are 10 explanatory variables $(n)$ and the sample size $(T)$ is 696. Therefore, $(n T) R^{2}=174.95$. The 1 percent critical value from the table is 15.056 , so based on White's test we can reject the null hypothesis of homoskedasticity. The Wald statistic is $7 * 10^{9}$ which is also highly significant. Therefore, all three tests lead us to reject the null hypothesis of homoskedasticity.

To solve the heteroskedasticity, we compute the GLS estimator assuming that variances are constant within subgroups of observations, see Judge et. al (1980), page 428. This gives the following result:

\begin{tabular}{|c|c|c|c|c|c|c|c|c|}
\hline$B_{t}=$ & $\begin{array}{l}0.39 \\
(0.07) \\
(5.49)\end{array}$ & $\begin{array}{cc}+\quad & 0.91 B_{t-1} \\
& (0.02) \\
& (54.32)\end{array}$ & & $\begin{array}{l}0.31 \Delta P_{t} \\
(0.39) \\
(-0.80)\end{array}$ & + & $\begin{array}{l}0.22 \Delta P_{t-1} \\
(0.38) \\
(0.58)\end{array}$ & + & $e_{t}$ \\
\hline \multicolumn{2}{|c|}{$R^{2}=0.81$} & \multicolumn{4}{|c|}{ Pooled Residual Variance $=1.02$} & \multicolumn{3}{|c|}{$\mathrm{DW}=2.06$} \\
\hline \multicolumn{4}{|c|}{ Sum of Squared Residuals $=721.63$} & \multicolumn{2}{|c|}{ Sample Size $=696$} & \multicolumn{3}{|c|}{ F-Stat $=983.79$} \\
\hline
\end{tabular}


Observe that the standard errors strongly decrease. Unlike the OLS pooled estimator, the GLS pooled estimator leads to the conclusion that the capital structure is explained not only by its past values but also by the constant term. However, inflation does not seem to have any explanatory power.

Doing some computation, we check that the standard deviation of capital structure $^{1}$ means across firms is 232.7 . This shows that the level of indebtedness varies strongly across firms. To take account of this factor we run a regression including 40 dummy variables, each one representing the intercept for every different firm. Results are shown in Table 2 (in attachments). Notice that the regression considering a unique intercept is the restricted least squared regression with 39 linear restrictions of the one including the dummy variables. Using this information, we can use the F statistic to test the null hypothesis that intercept does not vary over firms. The computed F statistic is

$$
F[39,654]=\frac{(721.6288-656.7238) / 39}{656.7238 / 654}=1.657 .
$$

The critical value from the $F$ table in the $95^{\text {th }}$ percentile is 1.5 , so we would reject the null hypothesis of homoskedasticity. Notice, however, that the inflation rate coefficients in the unrestricted regression are still statistically insignificant.

Finally, we consider the case when the slope coefficients vary over firms. We compute GLS following Judge et. al. (1980, pg. 539-40). Results are shown in Table 3 (in attachments). For a sample size of 696 , the student $t$ test for the null hypothesis that coefficients are zero is 1.96 . The overwhelming majority of coefficients are statistically insignificant. Only 7 companies out of 40 (American Express, Avon Products, Bell

\footnotetext{
${ }^{1}$ Capital structure is measure in percentage.
} 
Atlantic, Chrysler, General Motors, Eastman Kodak and Merrill Lynch) show a statistically significant coefficient, and six of them were negative.

\section{CONCLUSIONS}

This study considers a model of capital structure and the rate of inflation. The model is based on the theoretical contribution of a number of authors. Equation (6) summarizes all the effects considered in those articles. They embrace the Miller effect, the Schall effect, the DeAngelo-Masulis effect, and the Dammon effect. In a similar study, Kim and Wu (1988) find that inflation increases the level of debt, suggesting that the effect of the before-tax yield spread between corporate bonds and equities, and versus municipal bonds prevail, that is, the Miller and Schall effects dominate.

In a previous study by Kim and Wu (1988) using aggregate data, the Miller and Schall effect seems to dominate. However, the results we find here are not so conclusive. In those regressions where we assume a unique slope in the inflation coefficient, no relationship is found; yet even in the case when we allow slopes to vary, only one out of forty firms shows a negative slope. This may reflect some specific situations faced by that firm. Therefore, our findings suggest that no unique effect appears to dominate.

The paper can be regarded as the starting point of a more comprehensive empirical analysis between inflation and capital structure. A more interesting exercise would be to compute a simultaneous equation system to directly assess the weight of each effect. We did not do this here because of lack of data. To achieve a final conclusion, more work needs to be done. 


\section{REFERENCES}

Corcoran, P. "Inflation, Taxes and Corporate Investment Incentives." Federal Reserve Bank of New York Quarterly Review, 2, pp. 1-9.

Dammon, Robert M. (1988). "A Security Market and Capital Structure Equilibrium Under Uncertainty with Progressive Personal Taxes." Research in Finance.

DeAngelo, H. and R. Masulis (1980). "Optimal Capital Structure under Corporate and Personal Taxation." Journal of Financial Economics 8, March, pp. 3.29.

Dokko, Yoon (1989). "Are Changes in Inflation Expectations Capitalized into Stock Prices? A Micro-firm Test for the Nominal Contracting Hypothesis." Review of Economics \& Statistics, vol. 71 (2), May, pp. 309-17.

Franks, Julian R and Eduardo Schwartz (1991). "The Stochastic Behaviour of Market Variance Implied in the Prices of Index Options." Economic Journal, Vol. 101, November, (409), pp. 1460-75.

Hochman, S. and O. Palmon (1985). "The Impact of Inflation on the Aggregate DebtAsset Ratio.” Journal of Finance, 40, September, pp. 1115-1125.

Hodder, James E. and Lemma W Senbet (1990). "International Capital Structure Equilibrium." Journal of Finance, Vol. 45 (5), December, pp. 1495-1516.

Kelly, William and James Miles (1989). "Capital Structure Theory and the Fisher Effect." Financial Review, vol. 24 (1), February, pp. 53-73.

Kim, Moon K. and Chunchi Wu (1988). "Effects of Inflation on Capital Structure." The Financial Review, Vol. 23, No. 2, May, pp. 183-200.

Miller, Merton H. (1977). "Debt and Taxes." Journal of Finance May 32(2): 261-75. 
Modigliani, F. and M. H. Miller (1958). "The Cost of Capital, Corporate Finance and the Theory of Investment.” American Economic Review 48(3):261-297.

Platt, Harlan D. Marjorie B. Platt, and Guangli Chen (1995). "Sustainable Growth Rate of Firms in Financial Distress." Journal of Economics \& Finance, Vol. 19 (2), Summer, pp 147-51.

Schall, L. D. (1984). "Taxes, Inflation and Corporate Financial Policy.” Journal of Finance 39 (March), pp. 105-126.

Zwick, B (1977). “The Market for Corporate Bonds.” Federal Reserve Bank of New York Quarterly Review, 2, pp: 27-36. 
TABLE 1.

BREUSCH-GODFREY TEST FOR AUTOCORRELATION

\begin{tabular}{|c|c|c|c|c|}
\hline FIRM & $\operatorname{AR}(1)$ & $\mathrm{AR}(2)$ & $\operatorname{AR}(3)$ & $\operatorname{AR}(4)$ \\
\hline $\begin{array}{l}\text { CRITICAL VALUE FOR 99\% } \\
\text { CONFIDENCE }\end{array}$ & 6.63 & 9.21 & 11.34 & 13.28 \\
\hline ALLEGHENY TELEDYNE & 0.60 & 1.81 & 3.75 & 4.48 \\
\hline AMERICAN EXPRESS & 0.03 & 0.38 & 0.75 & 9.66 \\
\hline AMOCO CORP. & 0.26 & 1.44 & 5.70 & 9.24 \\
\hline AT\&T CORP & 0.05 & 0.26 & 6.90 & 6.58 \\
\hline AVON PRODUCTS & 0.17 & 0.96 & 4.35 & 7.56 \\
\hline BANKAMERICA CORP & 0.68 & 1.92 & 5.25 & 5.56 \\
\hline BELL ATLANTIC CORP & 0.51 & 0.80 & 1.50 & 2.24 \\
\hline BETHLEHEM STEEL CORP & 5.61 & 6.40 & 8.85 & 10.50 \\
\hline BLACK \& DECKER CORP & 0.27 & 0.64 & 2.85 & 6.58 \\
\hline BOEING & 1.16 & 1.56 & 2.70 & 3.36 \\
\hline CHRYSLER & 4.57 & 6.61 & 9.45 & 8.79 \\
\hline CITICORP & 1.62 & 8.16 & 9.90 & 11.05 \\
\hline COASTAL CORP & 2.36 & 6.34 & 3.86 & 3.63 \\
\hline COCA-COLA & 1.85 & 2.42 & 2.49 & 4.66 \\
\hline COLGATE-PALMOLIVE & 0.25 & 0.89 & 2.21 & 4.77 \\
\hline DELTA AIR LINES INC & 1.02 & 4.12 & 4.14 & 5.40 \\
\hline DIGITAL EQUIPMENTS & 0.25 & 4.39 & 5.01 & 4.90 \\
\hline DU PONT DE NEMOURS & 2.67 & 7.92 & 6.88 & 8.67 \\
\hline EASTMAN KODAK & 0.40 & 0.78 & 2.19 & 4.20 \\
\hline EXXON CORP & 0.08 & 1.58 & 1.49 & 3.50 \\
\hline FEDERAL EXPRESS & 0.17 & 1.60 & 1.90 & 3.60 \\
\hline FORD MOTORS & 0.17 & 0.96 & 1.95 & 3.22 \\
\hline GENERAL DYNAMICS & 0.40 & 0.32 & 10.7 & 12.1 \\
\hline GENERAL ELECTRIC & 0.15 & 0.40 & 2.10 & 3.36 \\
\hline GENERAL MOTORS & 1.87 & 2.30 & 2.40 & 2.10 \\
\hline HEINZ & 0.60 & 2.10 & 3.96 & 11.34 \\
\hline HEWLETT PACKARD & 2.38 & 3.84 & 3.90 & 3.78 \\
\hline INTEL & 1.09 & 1.53 & 6.60 & 6.69 \\
\hline JOHNSON \& JOHNSON & 1.93 & 2.40 & 3.75 & 4.48 \\
\hline McDONALDS & 3.74 & 3.84 & 6.99 & 7.28 \\
\hline MERCK & 2.72 & 5.92 & 8.25 & 8.54 \\
\hline MERRILL LYNCH & 0.02 & 0.96 & 3.00 & 6.64 \\
\hline MICROSOFT & 0.99 & 0.96 & 2.25 & 3.35 \\
\hline MOBIL & 0.01 & 1.57 & 3.3 & 5.74 \\
\hline PEPSICO & 0.02 & 3.36 & 3.75 & 6.02 \\
\hline SEARS ROEBUCK & 3.6 & 4.00 & 10.65 & 10.36 \\
\hline TEXAS INSTRUMENTS & 1.16 & 3.84 & 4.80 & 4.62 \\
\hline WAL-MART & 1.36 & 7.36 & 10.2 & 11.60 \\
\hline WALT DISNEY CO & 3.23 & 4.32 & 4.95 & 8.22 \\
\hline XEROX CORP & 0.02 & 1.76 & 2.70 & 4.62 \\
\hline
\end{tabular}




\section{TABLE 2. UNRESTRICTED REGRESSION}

Dependent Variable: $B_{t}$

Number of Observations: 696

\begin{tabular}{|c|c|c|c|}
\hline VARIABLE & COEFFICIENT & STD. ERROR & T-STAT \\
\hline Constant & 1.19 & 0.26 & 4.57 \\
\hline$B_{t-1}$ & 0.78 & 0.03 & 30.61 \\
\hline$P_{t}$ & -0.42 & 0.40 & -1.05 \\
\hline$P_{t-1}$ & -0.18 & 0.40 & -0.45 \\
\hline Dummy ALLEGHENY TELEDYNE & -0.64 & 0.34 & -1.89 \\
\hline Dummy BANKAMERICA CORP & -0.17 & 0.34 & -0.48 \\
\hline Dummy AMERICAN EXPRESS & -0.72 & 0.34 & -2.13 \\
\hline Dummy AMOCO CORP. & 0.62 & 0.39 & 1.61 \\
\hline Dummy AT\&T CORP & -0.49 & 0.34 & -1.44 \\
\hline Dummy AVON PRODUCTS & -0.89 & 0.34 & -2.59 \\
\hline Dummy BLACK \& DECKER CORP & 0.33 & 0.38 & 0.85 \\
\hline Dummy BELL ATLANTIC CORP & -0.88 & 0.34 & -2.54 \\
\hline Dummy BOEING & 0.01 & 0.37 & 0.01 \\
\hline Dummy CHRYSLER & -0.81 & 0.34 & -2.36 \\
\hline Dummy CITICORP & 0.21 & 0.35 & 0.60 \\
\hline Dummy COASTAL CORP & -0.54 & 0.34 & -1.60 \\
\hline Dummy COCA-COLA & 0.28 & 0.35 & 0.82 \\
\hline Dummy COLGATE-PALMOLIVE & -0.37 & 0.34 & -1.10 \\
\hline Dummy DIGITAL EQUIPMENTS & -0.57 & 0.35 & -1.63 \\
\hline Dummy DELTA AIR LINES INC & -0.59 & 0.34 & -1.73 \\
\hline Dummy WALT DISNEY & -0.25 & 0.36 & -0.69 \\
\hline Dummy DU PONT DE NEMOURS & -0.55 & 0.34 & -1.63 \\
\hline Dummy EXXON CORP & 0.07 & 0.36 & 0.19 \\
\hline Dummy FEDERAL EXPRESS & -0.45 & 0.34 & -1.31 \\
\hline Dummy FORD MOTORS & -0.30 & 0.34 & -0.88 \\
\hline Dummy GENERAL DYNAMICS & -0.57 & 0.34 & -1.67 \\
\hline Dummy GENERAL ELECTRIC & -0.51 & 0.34 & -1.50 \\
\hline Dummy GENERAL MOTORS & -0.89 & 0.35 & -2.56 \\
\hline Dummy HEINZ & -0.56 & 0.35 & -1.63 \\
\hline Dummy HEWLETT PACKARD & -0.03 & 0.36 & -0.10 \\
\hline Dummy INTEL & -0.68 & 0.34 & -1.98 \\
\hline Dummy JOHNSON \& JOHNSON & -0.26 & 0.35 & -0.76 \\
\hline Dummy EASTMAN KODAK & -0.87 & 0.34 & -2.52 \\
\hline Dummy McDONALDS & 0.40 & 0.36 & 1.11 \\
\hline Dummy MERCK & -0.38 & 0.35 & -1.09 \\
\hline Dummy MERRILL LYNCH & 1.13 & 0.36 & 3.16 \\
\hline Dummy MOBIL & -0.12 & 0.34 & -0.35 \\
\hline Dummy MICROSOFT & 1.01 & 0.79 & 1.29 \\
\hline Dummy PEPSICO & 0.31 & 0.34 & 0.89 \\
\hline Dummy SEARS ROEBUCK & -0.27 & 0.34 & -0.79 \\
\hline Dummy BETHLEHEM STEEL CORP & -0.64 & 0.34 & -1.89 \\
\hline Dummy TEXAS INSTRUMENTS & -0.11 & 0.35 & -0.33 \\
\hline Dummy WAL-MART & -0.05 & 0.34 & -0.14 \\
\hline
\end{tabular}

R-squared $\quad 0.827$

S. E. regression $\quad 1.003$

Sum of squared residuals

656.7238

Durbin Watson stat 2.002

$\mathrm{F}$ - statistic

74.401 
TABLE 3.

Dependent Variable: $B_{t}$

Number of Observations: 696

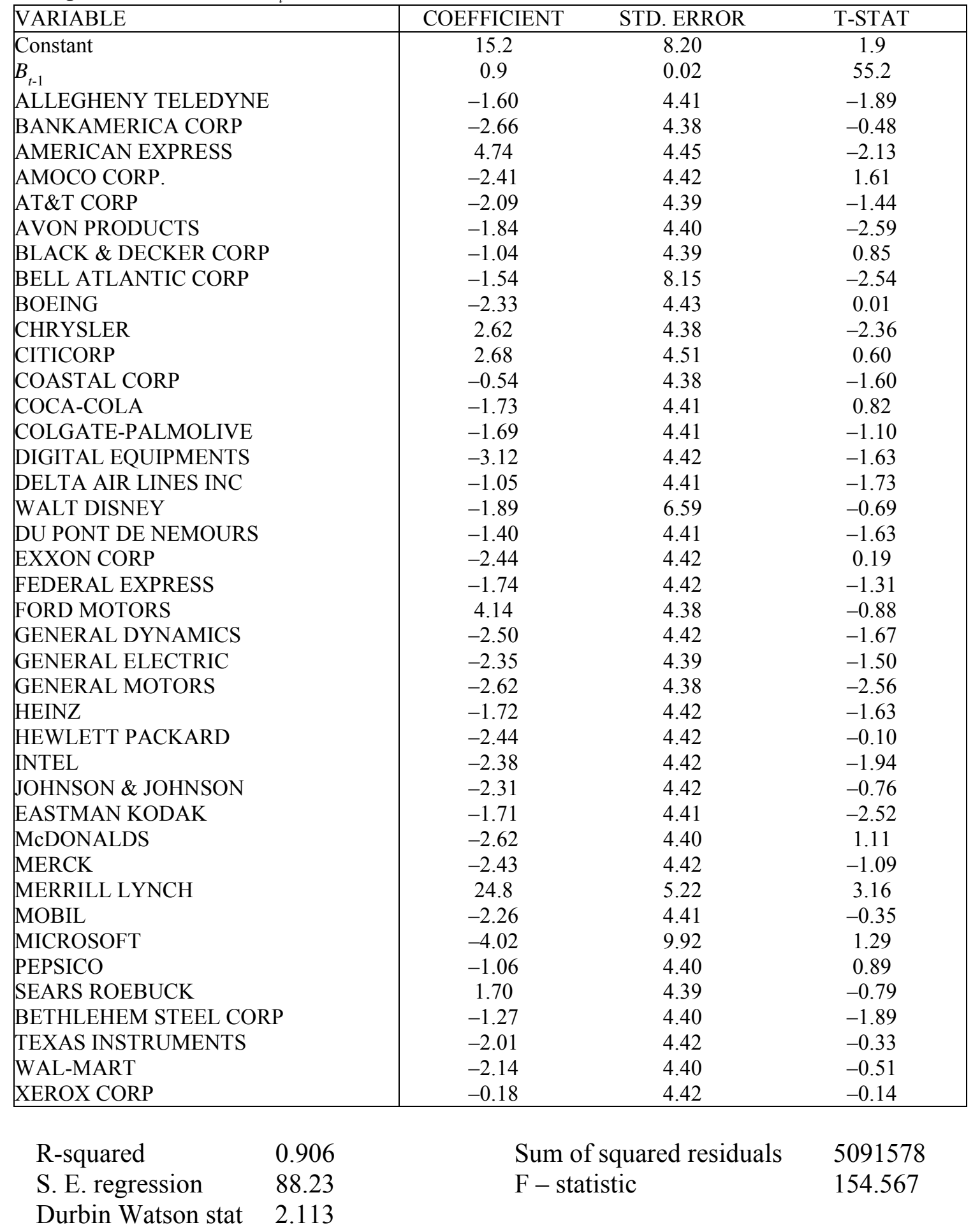

